\title{
Pemaknaan Profesi Beauty Vlogger melalui Pengalaman Komunikasi
}

\author{
Filza Intan Mariezka \\ Prodi Hubungan Masyarakat Fakultas IImu Komunikasi Universitas Padjadjaran \\ Email: filza.intanmariezka@gmail.com \\ Hanny Hafar \\ Prodi Hubungan Masyarakat Fakultas IImu Komunikasi Universitas Padjadjaran \\ Email: hannyhafiar@gmail.com \\ Yustikasari \\ Prodi Hubungan Masyarakat Fakultas IImu Komunikasi Universitas Padjadjaran \\ Email: filza.intanmariezka@gmail.com
}

\begin{abstract}
ABSTRAK
Di Indonesia, jumlah beauty vlogger terus mengalami peningkatan yang pesat semenjak 2015. Bahkan, sebagian besar dari mereka menjadikan kegiatan beauty vlogging sebagai pekerjaan tetap. Kemunculan dan perkembangan profesi ini juga menjadi sebuah bukti dari perkembangan teknologi informasi dan komunikasi. Penelitian ini bertujuan untuk mengetahui makna yang terbentuk dalam diri para pegiat beauty vlogger yang diarahkan melalui teori fenomenologi Schutz. Penelitian ini menggunakan pendekatan kualitatif dengan jenis studi fenomenologi. Teknik pengumpulan data yang digunakan wawancara mendalam, observasi partisipatif, dan studi kepustakaan. Sementara teknik validitas data menggunakan triangulasi sumber. Hasil penelitian menunjukkan bahwa beauty vlogger memaknai profesi mereka menjadi tiga makna, yaitu upaya aktualisasi diri, sebagai mata pencaharian, dan sebagai panutan.
\end{abstract}

Kata Kunci: Makna, profesi, beauty vlogger, pengalaman komunikasi

\section{ABSTRACT}

In Indonesia, the number of beauty vloggers continues to increase rapidly since 2015. In fact, most of them make beauty vlogging activities as a permanent job. The emergence and development of this profession is also a proof of the development of information and communication technology. This study aims to determine the meaning that formed in the beauty vlogger through Schutz's phenomenological approach. This study uses a qualitative approach with phenomenology as the type of study. Data collection techniques used in-depth interviews, participatory observation, and literature studies. While the data validity technique uses source triangulation. The results of this study showed that the beauty vlogger interpreted their profession into three meanings: selfactualization efforts, livelihood, and role models.

Keywords: Meaning, profession, beauty vlogger,communication experiences

\section{PENDAHULUAN}

Seiring dengan perkembangan teknologi informasi dan media sosial, pilihan profesi pun bertambah. Vlogger merupakan suatu profesi baru yang lahir sebagai bentuk dari perkembangan teknologi informasi dan media sosial. Salah satu jenis vlogger yang jumlahnya terus meningkat adalah beauty vlogger. Konten video yang dibuat oleh para pegiat profesi

Citation : Mariezka, Filza Intan, Hanny Hafar dan Yustikasari. (2018). “Pemaknaan Profesi Beauty Vlogger melalui Pengalaman Komunikasi”. Nyimak Journal of Communication, 2(2): 95-111. 
beauty vlogger adalah segala sesuatu yang berkaitan dengan kecantikan, makeup, tips dan trik, tutorial, dan lain-lain. Berdasarkan data dari statista.com, konten yang berhubungan dengan kecantikan menghasilkan lebih dari 55 miliar penayangan pada 2016, dan jenis konten kecantikan YouTube yang populer mencakup tutorial dan video DIY (do it yourself), ulasan, video haul, dan lain-lain. Sampai dengan Juni 2016, lebih dari 5,3 juta video kecantikan telah dipublikasikan di platform video online. Data ini mendukung fenomena yang terjadi saat ini, yaitu banyaknya wanita yang menjadikan beauty vlogger sebagai profesi (Warmbrodt, 2007).

Dari gambaran perkembangan berikut, terlihat perbedaan signifikan pada jumlah konten seputar kecantikan yang dibuat oleh beauty vlogger pada awal kemunculannya hingga 2017 pada masa perkembangannya. Kenaikan tertinggi terjadi pada 2017 dengan jumlah creator sebanyak 88 juta, sementara pada 2016 baru berjumlah 55 juta beauty creator.

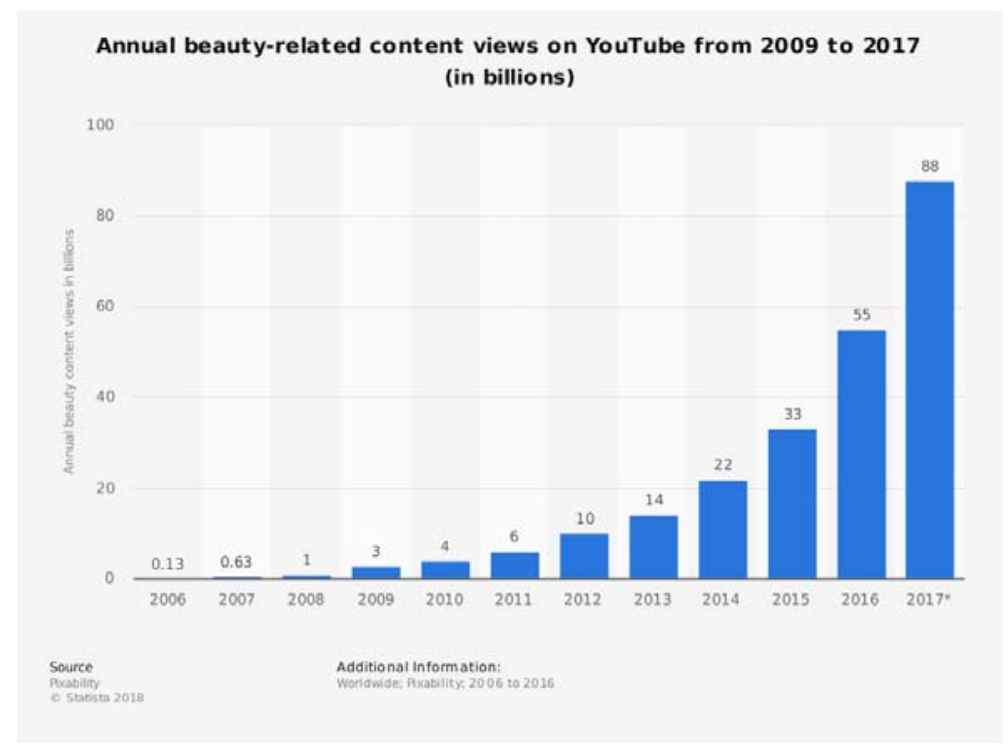
Gambar 1. Jumlah Tampilan Konten yang Berhubungan dengan Kecantikan di YouTube dari 2009-2017 (dalam Jutaan)

(Sumber: https://www.statista.com/statistics/294655/voutube-monthly-beauty-contentviews/)

Di Indonesia, profesi beauty vlogger baru dimulai sekitar 2015 serta mengalami perkembangan yang cukup pesat hingga saat ini. Jihan Putri Zuariah, salah satu beauty vlogger yang tergabung dalam Komunitas Indo Beauty Vlogger (IBV), mengemukakan bahwa anggota IBV baru berjumlah 30 orang pada 2015 ketika dirinya pertama kali ikut bergabung, kemudian bertambah menjadi 50 orang pada 2016, dan pada 2018 sudah memiliki lebih dari 100 anggota. 
Salah seorang beauty vlogger yang memulai karirnya secara tidak sengaja adalah Stephanie Rose. Dikutip dari Video Question and Answer atau yang lebih sering disebut QnA yang diunggah pada tanggal 24 November 2017, Stephanie Rose menceritakan bagaimana awal kariernya menjadi seorang beauty vlogger.

Banyak perempuan yang tergiur untuk mencoba peruntungannya sebagai beauty vlogger karena syarat untuk menjadi beauty vlogger tidak susah. Pada dasarnya, semua perempuan bisa menjadi beauty vlogger. Modal utamanya yang paling penting adalah keahlian berdandan dan kepercayan diri. Tak perlu kamera mahal dan produk kosmetik yang mahal pula. Jika kualitas gambar video yang dihasilkan kamera handphone sudah baik maka tidak perlu lagi kamera profesional seperti DSLR. Begitu pula dengan produk kosmetik yang digunakan. Saat ini kualitas produk kosmetik lokal pun tidak kalah bagus dengan produk luar negeri yang harganya mahal. Banyak produk kosmetik lokal yang bisa didapatkan dengan harga terjangkau dan kualitas baik.

Beauty vlogger lainnya, Ratu, juga menuturkan kemudahan lain yang menjadi pendorong dirinya menjadi seorang beauty vlogger. Ratu termotivasi untuk membuat video beauty karena minimnya persyaratan yang dibutuhkan untuk melakukan hal itu. Kemudahan lainnya adalah karena ia tidak perlu pergi keluar rumah untuk melakukan beauty vlogging. Walaupun ketika pembuatan video pertama kemampuan makeupnya masih pas-pasan, tapi Ratu berani dan percaya diri untuk membuat video dan meng-upload-nya ke YouTube. Tidak disangka, respon yang didapat pun baik dan ia semakin termotivasi untuk terus membuat video.

Sementara itu, profesi beauty vlogger juga sudah mulai dirlirik dan mendapat respon positif dari industri kecantikan. Banyak merek kecantikan yang semakin percaya akan kekuatan yang dimiliki vlogger dalam "menghinoptis" para audiensnya. Cukup lazim apabila beauty vlogger mulai mendapat tempat di hati berbagai merek kosmetik. Karena, konsumen di era digital sudah jenuh dan cenderung tidak percaya akan pesan merek yang selama ini disampaikan melalui iklan televisi. Perempuan kini mencari seseorang yang mampu berkata apa adanya, serta paham betul akan dunia kecantikan. Orang itu benar-benar yang dapat mereka ajak bicara. Semua karakter itu dapat ditemui pada sosok seorang beauty vlogger.

Patricia Husada (dalam Bachdar, 2017), GM Marketing PT. Martina Berto Tbk., produsen kosmetik Sariayu menuturkan bahwa salah satu keunggulan merek kosmetik menggunakan beauty vloggers adalah mereka dapat mengedukasi mengenai kegunaan produk kepada target pasar yang disasar secara lebih jelas. Vlogger membantu dalam memberikan tutorial makeup, atau bagaimana cara menggunakan produk-produk kami dengan benar. Suara dari para vlogger menjadi lebih didengar. Dengan demikian, dapat dikatakan bahwa melalui vlogger, brand menjadi lebih efektif untuk menyampaikan pesan kepada audiens. 
Vlog sebagai bukti perkembangan media digital, turut membuka cara baru untuk menghasilkan PR coverage dan sangat mampu diandalkan untuk memberikan pengaruh (influence) serta menarik perhatian dari sejumlah konsumen. Vlogger dianggap sebagai orang yang kredibel dan ahli pada bidangnya sehingga mereka dapat memengaruhi para penontonnya melalui ulasan dan tutorial yang mereka buat (Seehan, 2016). Dalam hal ini, beauty vlogger yang memberi ulasan dan tutorial tentang suatu produk kecantikan dapat mempengaruhi penontonnya untuk mengambil keputusan dalam membeli makeup atau skincare.

Dalam literatur, video blog atau vlog didefinisikan sebagai blog yang diunggah dalam bentuk video (Warmbrodt, 2007). Meskipun dalam video tersebut terdapat teks, fokusnya tetap saja ke dalam video. Para vlogger mengembangkan konten vlog mereka menjadi lebih menarik dan mengedukasi sehingga dapat bermanfaat bagi para penonton vlognya. Topik yang saat ini banyak dibahas dalam vlog adalah menceritakan mengenai pengalaman dan ketertarikan terhadap sesuatu, seperti games, wisata kuliner, termasuk juga kecantikan.

Vlogger bisa dikategorikan sebagai YouTuber, bisa sebagai individu, kelompok, komunitas, atau perusahaan besar yang memproduksi video-video uniknya sendiri yang khusus untuk ditampilkan di YouTube. Bahkan, sebagian dari mereka berhasil meraih kesuksesan dan menjadikan YouTube sebagai sumber mata pencaharian (Dahlan, 2015). Sayangnya, pandangan masyarakat terhadap profesi ini masih belum begitu baik, karena mereka belum mengerti bagaimana proses mendapatkan uang dari YouTube. Karena itu, mereka menganggap vlogger bukan sebagai pekerjaan, melainkan hanya untuk "main-main". Padahal, ada potensi yang bisa dijadikan sebagai sumber uang bagi para vlogger.

Pertama, Monetizing Options dari YouTube atau Google ketika seorang vlogger mengupload video di YouTube, di mana yang bersangkutan diberi pilihan untuk dapat menyalakan pilihan Monetize (monetisasi video). Artinya, pemilik video mengizinkan YouTube atau Google menempatkan iklan di dalam videonya. Sebagai timbal baliknya, pemilik video akan mendapat bagi hasil dari iklan, dengan pembagian 45 persen untuk YouTube dan 55 persen untuk pemilik video.

Kedua, Brand Deals. Memiliki subscriber dan viewer tinggi adalah sama artinya dengan memiliki massa yang setia melihat video yang diunggah pemilik akun, Pada era informasi ini, massa adalah raja. YouTuber yang memiliki massa dapat menarik banyak potensi untuk sponsor, pengiklan luar YouTube, atau bahkan program investor ke dalam channel YouTubenya, dan ini adalah sumber income lainnya dari YouTube. Dengan mendapatkan sponsor, YouTuber bisa mendapatkan bayaran untuk menempatkan brand placement atau iklan di 
luar sistem Google ke dalam video mereka dengan harga variatif tergantung sepopuler apa channelnya dan sedalam apa keuntungan yang bisa didapatkan para sponsor.

\section{METODE PENELITIAN}

Penelitian ini menggunakan paradigma konstruktivisme. Paradigma ini secara tegas menolak pandangan positivisme yang memisahkan subjek dan objek komunikasi. Subjek penelitian ini adalah beauty vlogger, sementara objeknya adalah pemaknaan dari profesi beauty vlogger. Penelitian ini menggunakan pendekatan fenomenologi, sebuah pendekatan yang memberi pemahaman bahwa dunia adalah sesuatu yang dikonstruksi secara intersubjektif dan merefleksikan pengalaman langsung manusia. Pada penelitian ini, manusia yang dimaksud adalah para beauty vlogger sebagai individu, yang memiliki pengalaman dan perspektif sendiri selama menjalani profesi beauty vlogger. Sementara itu, penentuan informan dalam penelitian dipilih secara purposive sampling.

Teknik pengumpulan data yang digunakan dalam penelitian ini ialah wawancara mendalam, observasi, studi pustaka, dokumentasi, dan penelusuran online. Triangulasi yang digunakan adalah triangulasi sumber data, yaitu untuk menghilangkan perbedaan-perbedaan konstruksi kenyataan selama proses pengumpulan data menyangkut berbagai kejadian dan hubungan dari berbagai pendangan.

\section{HASIL DAN PEMBAHASAN}

Sebuah makna muncul dari hubungan khusus yang terjadi di antara kata (sebagai simbol verbal) dan manusia. Kesadaran pada individu yang mengalami fenomena secara langsung dapat membentuk suatu makna. Dalam penelitian ini, individu yang menjalani profesi sebagai beauty vlogger secara langsung menjalani kehidupan dengan kegiatan beauty vlogging sekaligus memaknai profesinya sesuai dengan pengalamannya selama menjadi beauty vlogger. Individu yang memiliki pekerjaan yang sama belum tentu dapat memaknai pekerjaan mereka dengan sama pula. Tentu ada perbedaan dalam memaknai dan menginterpretasi pekerjaan yang mereka lakukan, termasuk juga pekerjaan sebagai beauty vlogger.

\section{Makna Aktualisasi Diri}

Media sosial sekarang banyak digunakan untuk mengekspresikan emosi tertentu yang dialami oleh seseorang. Hal ini merupakan salah satu bentuk pengungkapan diri atau self disclosure, yaitu komunikasi yang disengaja melalui perilaku verbal yang salah satu tujuannya ialah untuk menjelaskan mengenai pengalaman atau perasaan seseorang (Arnus, 2016; Ayudhya, 2017; Ayun, 2015; Barazova \& Choi, 2014; Mahendra, 2017; Sagiyanto \& Ardiyanti, 
2018). Salah satu aktivitas aktualisasi diri melalui media sosial tersebut yang akhir-akhir ini marak adalah aktivitas vlogging.

Para vlogger tersebut mengemas konten vlog mereka menjadi lebih menarik dan mengedukasi sehingga bermanfaat bagi penonton. Topik yang saat ini banyak dibahas dalam vlog adalah menceritakan tentang pengalaman dan ketertarikan terhadap sesuatu, seperti games, wisata kuliner, termasuk juga kecantikan.

Lima beauty vlogger yang berkesempatan menjadi informan pada penelitian ini memaknai profesinya sebagai sarana untuk mengaktualisasikan diri. Salah satu modal utama mereka, yaitu memberanikan diri menjalani profesi sebagai beauty vlogger, ialah karena memiliki perhatian lebih terhadap dunia kecantikan, atau mereka lebih sering disebut sebagai beauty enthusiast. Memiliki hobi dan passion di bidang kecantikan atau beauty menjadikan profesi beauty vlogger sebagai sarana bagi aktualisasi diri.

Pemberian makna aktualisasi diri itu dilakukan melalui sebuah proses produksi makna yang dikelola dan diorganisasikan berdasarkan hubungan dengan pengelolaan informasi atau pengalaman sealama menjadi beauty vlogger. Schutz dengan pandangan fenomenologinya menyebut proses tersebut sebagai stock of knowledge, yaitu proses pengumpulan pengalaman yang memengaruhi makna yang terkonstruksi dalam pola pikir, gerak, sikap, perilaku dan bisa diaplikasikan serta diimplementasikan secara nyata dalam kehidupan (Kuswarno, 2009). Para informan memaknai bahwa menekuni profesi sebagai beauty vlogger adalah sarana untuk mengaktualisasikan diri melalui unggahan video yang mereka buat seputar dunia kecantikan, seperti makeup, perawatan kulit, tips kecantikan, dan berdandan. Tak hanya melalui unggahan video, pengalaman kerja sama yang dilakukan dengan banyak pihak, terutama brand makeup, juga ikut memengaruhi makna yang diberikan dalam menekuni profesi sebagai beauty vlogger.

Menurut Siswandi (dalam Soetanto, 2016), aktualisasi diri memberi perhatian kepada manusia, khususnya terhadap nilai-nilai martabat secara penuh. Hal tersebut bisa tercapai melalui penggunaan segenap potensi, bakat, dan kemampuan yang dimiliki dengan bekerja sebaik-baiknya sehingga tercapai suatu keadaan eksistensi yang ideal bagi pertumbuhan dan perkembangan diri. Rogers (dalam Soetanto, 2016) mengatakan bahwa aktualisasi diri merupakan proses menjadi diri sendiri dan mengembangkan sifat-sifat dan potensi-potensi psikologis yang unik. Aktualisasi diri akan dibantu atau malah dihalangi oleh pengalaman belajar khususnya pada masa kanak-kanak. Aktualisasi akan berubah sejalan dengan perkembangan hidup seseorang ketika mencapai usia tertentu, dan akan mengalami pergeseran dari tahap fisiologis ke psikologis. Rogers menyatakan bahwa setiap orang memiliki kebutuhan aktualisasi diri untuk mengembangkan seluruh potensinya. Menurut 
pendapat Rogers, pada hakikatnya manusia memiliki potensi untuk tumbuh dan berkembang ke arah yang lebih baik. Jadi, aktualisasi diri dapat dimaknai sebagai keinginan bawaan individu untuk mengembangkan potensi yang dimilikinya dan mencapai prestasi sesuai dengan bidangnya masing-masing,

Penjelasan mengenai aktualisasi diri tersebut sejalan dengan hasil penelitian ini. Salah satu informan yang memiliki hobi melukis sejak kecil mengembangkan hobinya seiring pertumbuhan usianya. Memasuki usia remaja, ia mengembangkan kegemaran tersebut ke dunia kecantikan atau makeup. Setelah informan tersebut menyelesaikan kuliahnya, ia memilih profesi sebagai beauty vlogger agar dapat memenuhi kebutuhan aktualisasi dirinya. Bukan memilih pekerjaan sesuai dengan bidang kuliahnya.

Maslow menyatakan bahwa individu yang mengaktualisasikan dirinya memiliki ciri-ciri sebagaimana berikut ini (dalam Soetanto, 2016).

1. Persepsi yang tepat terhadap realita. Artinya, individu ini dapat melihat dunia secara jernih tanpa dipengaruhi oleh keinginan, kebutuhan, atau sikap emosional.

2. Fokus pada target pencapaian, berarti individu tersebut mengaktualisasikan dirinya dengan melakukan hal-hal yang terbaik atau bekerja sebaik-baiknya sesuai dengan bidangnya masing-masing.

3. Mempunyai spontanitas, yakni bisa bertingkah laku secara terbuka tanpa malu-malu karena lebih ekspresif, jujur (tidak dibuat-buat), dan wajar.

4. Bisa menerima diri sendiri dan orang lain dengan baik, individu dapat menghormati diri sendiri dan orang lain, serta mampu menerima kodrat dengan segala kekurangan dan kelemahannya. Individu juga cenderung untuk menjalin hubungan akrab, baik, dan penuh rasa kasih sayang dengan orang lain.

Menurut Anari (dalam Soetanto, 2016), faktor-faktor yang dapat memengaruhi aktualisasi diri antara lain kreativitas, transendensi, demokratis, dan hubungan sosial. Cara yang digunakan seseorang agar dapat mencapai aktualisasi diri menurut Maslow (dalam Soetanto,2016) adalah adanya kemauan untuk berubah, memiliki sikap tanggung jawab, motivasi hidup, pengalaman yang jujur dan langsung, siap untuk bersikap beda, melibatkan diri, dan menilai kemajuan diri.

Dalam konteks aktualisasi diri dan fenomena beauty vlogger, Nurfah Fitriani melihat bahwa seseorang yang menekuni profesi sebagai vlogger merupakan bagian dari pemenuhan kebutuhan dirinya. Kebutuhan tersebut terpisah menjadi dua bagian, yaitu deficiency needs 
meliputi empat tahap yang harus dipenuhi sebelum seseorang mampu untuk mencapai kepuasan intelektual yang lebih baik dengan growth needs. Dinamika kebutuhan yang terjadi pada profesi vlogger saling berkesinambungan. Dengan konten yang dihasilkan, vlogger dapat memenuhi baik kebutuhan defisiensi (deficiency needs) berupa rasa aman (misalnya karena menghasilkan uang), kebutuhan akan kasih sayang (misalnya penerimaan dari penikmat konten), maupun kebutuhan akan penghargaan (misalnya vlogger dihormati karena keahliannya). Tak menutup kemungkinan vlogging dijadikan sebagai media atau sarana dalam memenuhi kebutuhan untuk bertumbuh (growth needs), yang dapat dicapai melalui kognitif (kebutuhan untuk mengetahui dan mengerti), estetika (kebutuhan yang berkenaan dengan keteraturan dan keindahan), serta dua kebutuhan terakhir yang mendefinisikan tujuan hidup, mengarah pada spiritual yang intens dan pemenuhan psikologis (aktualisasi diri dan selftranscendence). Artinya, aktualisasi diri merupakan pemenuhan potensi pribadi, dan selftranscendence adalah kebutuhan untuk bergerak melampaui diri sendiri serta terhubung dengan sesuatu yang lebih tinggi dari dirinya (misal Tuhan). Selain itu, dengan self-transcendence, individu juga dapat menolong orang lain untuk menyadari potensi mereka.

\section{Makna Mata Pencaharian}

Mata pencaharian dapat didefinisikan sebagai pekerjaan utama yang dilakukan seseorang guna mendapatkan keuntungan yang biasanya dalam bentuk uang atau materi lainnya. (Prambudi, 2010) menyatakan bahwa mata pencaharian merupakan pekerjaan pokok yang dilakukan oleh masyarakat. Setiap individu dalam masyarakat harus punya pekerjaan pokok untuk menopang kebutuhan ekonomi mereka. Seseorang memilih pekerjaan yang kemudian menjadi profesi tertentu sebagai mata pencahariannya, dengan tujuan untuk mendapatkan keuntungan, yaitu uang. Salah satu mata pencaharian sebagai usaha untuk mendapat penghasilan berupa uang ialah beauty vlogger (Mahameruaji (et al.), 2018; Moor, Heuvelman \& Verleur, 2010; Murthy, 2012; Tolson, 2010).

Kata profesi berasal dari bahasa Latin professeus, berarti suatu kegiatan atau pekerjaan yang semula dihubungkan dengan sumpah dan janji yang bersifat religius (Rismawaty, 2008). De George mendefinisikan profesi sebagai sebuah pekerjaan yang dilakukan sebagai kegiatan pokok untuk menghasilkan nafkah hidup dan mengandalkan suatu keahlian dengan landasan moral yang relijius. Sementara itu, Gilley dan Eggland (dalam Suwinardi, 2017) mendefinisikan profesi sebagai sebuah bidang usaha manusia berdasarkan pengetahuan di mana keahlian dan pengalaman pelakunya diperlukan oleh masyarakat. Profesi juga dibedakan menjadi profesi khusus yang berarti profesional yang melaksanakan profesi secara khusus dengan tujuan utama mendapatkan nafkah atau penghasilan tertentu dan profesi luhur, 
yaitu para profesional yang melaksanakan profesinya sebagai bentuk jiwa pengabdiannya semata-mata serta dedikasi, tidak lagi bertujuan utama untuk mendapatkan nafkah.

Dalam penelitian ini, beauty vlogger dapat dikategorikan sebagai profesi luhur, karena informan menjadikan kegiatan beauty vloggingnya sebagai mata pencaharian untuk mendapatkan nafkah dan penghasilan. Definisi yang diberikan oleh Gilley dan Eggland sejalan dengan fenomena beauty vlogger yang ada saat ini. Menjadi seorang beauty vlogger adalah usaha yang dilakukan berdasarkan pengetahuan serta keahlian, khususnya tentang makeup, videografi, pengalaman para beauty vlogger (misal keahlian merias diri), dan dibutuhkan oleh masyarakat yang mencakup para pengguna YouTube sebagai penonton beauty vlog dan brand sebagai pihak yang biasa bekerja sama dengan beauty vlogger. Jadi, beauty vlogger mendapat pengakuan dari masyarakat (profesional, penguasa, dan awam). Seperti yang diungkapkan oleh salah satu informan, kerja sama yang terjalin antara beauty vlogger dengan brand sifatnya resmi dan profesional. Karena itu, para beauty vlogger pun bertindak profesional dalam kerja sama yang dijalinnya.

Profesional merujuk pada dua hal. Pertama, yaitu orang yang menyandang suatu profesi tertentu, misalnya seperti ungkapan dia seorang profesional. Kedua, penampilan seseorang dalam melakukan sebuah pekerjaan yang sesuai dengan profesinya. Dalam pengertian kedua ini, istilah profesional dikontraskan dengan "nonprofesional" atau "amatir". Dalam kegiatan sehari-hari, seorang profesional melakukan pekerjaan sesuai dengan ilmu yang telah dimilikinya, tidak asal tahu saja. Profesionalisme merujuk pada komitmen para anggota suatu profesi untuk meningkatkan kemampuan profesionalnya dan secara terus menerus mengembangkan strategi-strategi yang digunakannya dalam melakukan pekerjaan yang sesuai dengan profesinya. Profesionalitas, pada pihak lain, mengacu pada sikap para anggota profesi terhadap profesinya serta derajat pengetahuan dan keahlian yang mereka miliki dalam rangka melakukan pekerjaannya. Jadi, seorang profesional tak akan mau mengerjakan suatu pekerjaan yang memang bukan bidangnya (Satori, 2005).

Terkait dengan penelitian ini, profesi profesional adalah bagian dari pemaknaan mata pencaharian. Informan mengartikan profesional sebagai orang yang menyandang suatu profesi yakni sebagai beauty vlogger. Dalam menekuni profesinya, para informan menunjukkan profesionalisme dengan berkomitmen terus meningkatkan kemampuan profesional dandan atau meriasnya dan terus mengembangkan strategi-strategi yang digunakan dalam pekerjaan membuat sebuah video kecantikan dan makeup. Walaupun sudah dipandang sebagai beauty vlogger andal, para informan masih terus belajar pada sesama beauty vlogger dan menonton video-video beauty vlogger dari luar negeri yang juga menjadi idola mereka. Biasanya kegiatan sharing ilmu, pengalaman, dan acara sesama beauty vlogger 
dilakukan salah satunya lewat grup komunitas Indonesia Beauty Vlogger IIBV) di media sosial Line, ketika menghadiri acara peluncuran produk, atau peresmian booth. Profesionalitas beauty vlogger mengacu kepada sikap para pegiatnya terhadap profesi yang mereka tekuni dan keahlian yang dimiliki sebagai beauty vlogger.

Pada sisi lain, tak bisa dipungkiri bahwa menjalani profesi beauty vlogger dapat menghasilkan pundi-pundi rupiah. Video yang dihasilkan oleh beauty vlogger dapat "memproduksi" uang berdasarkan sistem monetized video yang dimiliki oleh YouTube. Niken Sasmaya, dikutip dari antaranews.com, menyatakan bahwa sistem monetisasi bagi kreator berjalan secara otomatis, dimulai sejak para kreator membuat channel YouTube hingga mengunggah konten original. Menurutnya, secara otomatis kreator sudah berhak untuk memonetisasi video mereka. Jadi, hanya ada satu tombol yang perlu diklik di pengaturan YouTube untuk melakukan monetisasi pada channel. Setelah itu, bisa dilakukan pengaturan apakah video akan diberi iklan atau tidak; semua pengaturan tersebut ada dan pendapatannya secara otomatis akan mengalir. Niken menambahkan bahwa terdapat pengaruh dari kebijakan suatu negara untuk memberikan izin apakah video tersebut layak untuk dimonetisasi.

Selain bisa mendapatkan uang dari video yang dimonetisasi, beauty vlogger bisa melakukan kerja sama dengan berbagai pihak untuk mempromosikan produk tertentu dari suatu brand. Dalam kerja sama tersebut, biasanya beauty vlogger mempunyai rate card yang merupakan panduan dalam melakukan kerja sama, sementara pihak brand memiliki Memorandum of Understanding (MoU) atau nota kesepahaman bagi dua belah pihak. Dalam rate card tersebut, dijelaskan tentang syarat dan ketentuan yang diberikan beauty vlogger dalam melakukan kerja sama. Pihak perusahaan juga harus memahami syarat dan ketentuan yang dimiliki oleh beauty vlogger melalui rate card yang disusun. Dalam konteks ini, harga yang ditentukan oleh beauty vlogger didasarkan pada jumlah followers dan subscribers. Hal ini bertujuan untuk memperirakan berapa besar pengaruh yang dapat diberikan beauty vlogger kepada perusahaan tersebut.

Biasanya, beauty vlogger diminta untuk mempromosikan atau membahas suatu produk tertentu dari brand dalam video tutorial akan video review secara khusus. Demi profesionalitas, para beauty vlogger melakukan persiapan khusus sebelum melakukan shooting produk. Mereka terlebih dulu membuat script sebagai panduan. Biasanya yang dibicarakan adalah manfaat atau kegunaan produk. Apabila pada kenyataannya produk tersebut tidak sesuai untuk jenis kulit mereka maka penggunaan kata yang tepat harus diperhatikan. Tak mungkin seorang beauty vlogger yang sudah diberi kepercayaan oleh perusahaan untuk mengulas produknya malah menjelek-jelekan produk tersebut dalam videonya. Secara etis, hal itu juga tak pantas dilakukan. Karena itu, beauty vlogger bisa memahami poin-poin yang 
harus diperhatikan dalam membuat sebuah video kolaborasi dengan brand tertentu berdasarkan MoU.

Tak hanya kerja sama untuk membuat video, beauty vlogger dengan brand juga bekerja sama dalam meluncurkan produk yang merupakan kolaborasi antara brand dan beauty vlogger. Salah seorang beauty vlogger ternama, Rachel Goddard, meluncurkan produk lipstik yang berkolaborasi dengan brand makeup lokal, yaitu Mizzu Cosmetics yang diberi nama "Mermaid Lipstik". Mereka juga bekerja sama dengan brand NIVEA dan membuat paket yang berisi produk kolaborasi mereka (Akto, 2018).

Bagian lainnya dari pemaknaan profesi beauty vlogger sebagai mata pencaharian adalah karena profesi ini dianggap sebagai sebuah industri baru. Profesi beauty vlogger menggabungkan dua industri yang sudah ada sebelumnya, yaitu industri kecantikan dan industri media digital. Saat ini, perkembangan industri kecantikan ikut dipengaruhi oleh industri media digital. Kecenderungan perilaku wanita yang saat ini seolah-olah tidak bisa lepas dari makeup, membuat industri kecantikan menjadi salah satu sektor industri dengan pertumbuhan tercepat di Indonesia. Menurut laporan dari Beauty Market Survey (BMS) yang dikutip dari Nielsen dan Euro Monitor, nilai industri kosmetik di Indonesia secara keseluruhan mencapai 36 triliun pada 2016, dan produk skin care menyumbang sekitar 31,7 persen (Putri, 2018). Sementara itu, dikutip dari cnnindonesia.com, Menteri Perindustrian Airlangga Hartanto juga mengatakan bahwa tren masyarakat menjadikan produk kecantikan sebagai kebutuhan utama menopang pertumbuhan industri kosmetik, dan Kemenperin telah menetapkan industri kosmetik sebagai sektor andalan.

Semenjak munculnya beauty vlogger, makeup menjadi topik pembicaraan yang tidak pernah habis dan selalu menarik untuk dibahas. Para perusahaan brand juga sudah mengandalkan beauty vlogger dalam kegiatan promosi mereka dan mulai meninggalkan para artis. Justru, para artis mulai merambah industri kecantikan ini dengan membuat brand kosmetiknya sendiri. Banyak brand makeup yang muncul dalam beberapa tahun belakangan ini, mulai dari lipstik, skin care, body care, dan produk makeup lainnya. Mereka yang memulai kariernya sebagai beauty vlogger pun sudah ada yang memiliki brand makeupnya sendiri, seperti Lizzie Parra dengan brand BLP (by Lizzie Parra). Selain itu, para artis yang biasa menjadi model iklan suatu produk, kini sudah membuat brand makeupnya sendiri, misalnya Zaskia Adya Mecca dengan produk lipstik cairnya ZAM Cosmetics, Valerie Thomas merilis produk lipstik VAL, dan Ussy Sulistiawati dengan berbagai macam produk makeup dan skin care Dissy (Oktaviani, 2017). 
Dalam penelitian yang dilakukan oleh Rahmawan, Hafiar dan Narotama (2017), disebutkan bahwa Indonesia sebagai negara yang memiliki penetrasi internet dan media sosial tinggi, model bisnis baru seperti vlogger ini menjadi salah satu perbincangan hangat di kalangan pelaku industri media digital. Dalam penelitian tersebut, salah satu responden yang berkecimpung dalam industri periklanan menuturkan bahwa ia kerap mencari informasi melalui Forum Social Media Strategist Club di Facebook untuk dapat menentukan vlogger seperti apa yang cocok digunakan untuk kampanye periklanan yang sedang ia kerjakan. Dalam perjalanannya, seiring dengan meningkatnya jumlah subscriber yang mereka miliki, basis massa mereka pun semakin meluas, dan tarif untuk menggunakan jasa mereka juga semakin tinggi.

\section{Makna sebagai Panutan}

Para informan dalam penelitian ini memaknai profesinya sebagai panutan dalam bermakeup. Berbagai macam teknik makeup yang diperagakan, produk-produk yang digunakan, dan tampilan makeup yang dihasilkan dapat dijadikan acuan para penonton video tentang beauty yang dibuat oleh beauty vlogger. Kebiasaan para penonton beauty vlog adalah mencari kesamaan antara dirinya dengan beauty vlogger. Hal ini bertujuan untuk mendapatkan pertimbangan atau gambaran tentang produk serta bagaimana hasil dan kesannya pada jenis kulit sang beauty vlogger.

Kecenderungan para informan yang suka sharing dan berbagi informasi tentang pengetahuannya mendukung makna profesinya sebagai panutan. Informan senang untuk memberikan informasi baru dan berbagi pengalamannya dalam menggunakan produk-produk kecantikan. Selain itu, informan juga berusaha memberitahu informasi secara detail agar para penonton videonya mengerti apa yang dimaksud dalam video tersebut. Selain itu, informan juga menuliskan informasi tersebut dalam description box, tepatnya di bagian bawah layar video.

Pernyataan yang diungkapkan informan dalam hasil penelitian sesuai dengan salah satu asumsi teori interaksi simbolik, di mana makna diciptakan dalam interaksi manusia. Asumsi ini menjelaskan bahwa individu membentuk makna melalui proses komunikasi dan tujuannya adalah untuk menciptakan makna yang sama. Hal ini menjadi penting karena apabila tidak menciptakan makna yang sama maka komunikasi itu akan menjadi sulit atau bahkan tidak terjadi (dalam West \& Turner, 2007).

Karena itu, beauty vlogger dapat berperan dan dimaknai sebagai panutan karena mereka secara tak langsung memberi pengaruh (influence) kepada penontonnya melalui video yang dibuat. Dalam videonya, tentu mereka membahas produk yang mereka sukai dan mereka rekomendasikan atau yang baru mereka gunakan pada saat perekaman video tersebut. Pada 
akhirnya, banyak penonton yang "teracuni" dengan produk-produk yang dibicarakan beauty vlogger mulai dari produk makeup, skin care sampai dengan teknik yang biasa dipergunakan beauty vlogger. Melihat kekuatan yang dimiliki beauty vlogger dalam memengaruhi penonton (viewer) dan pelanggan (subscriber), banyak perusahaan khususnya brand kecantikan dan yang berkaitan dengan gaya hidup mengajak beauty vlogger bekerja sama dan menjadikan mereka sebagai alat promosi perusahaannya, baik brand luar negeri yang sudah memiliki nama dan posisi sendiri di masyarakat, seperti Maybelline, L'Oreal, The Body Shop dan lainlain, maupun brand lokal dan brand indie seperti Avoskin, Elsheskin, ZAP, dan lain-lain.

Dalam konteks ini, pengaruh adalah salah satu elemen dalam komunikasi yang penting untuk mengetahui besar tidaknya komunikasi yang kita inginkan (dalam David, 2017). Carl I. Hovland (dalam David, 2017) menyatakan bahwa komunikasi merupakan suatu proses mengubah perilaku orang lain (communication is the process to modify the behavior of other individuals). Lebih dari itu, perubahan perilaku adalah tujuan tertinggi kegiatan komunikasi dalam perspektif individual, tujuan yang lebih rendah tingkatannya adalah perubahan sikap dan perubahan pandangan. Dalam konteks penelitian ini, beauty vlogger yang dimaknai sebagai panutan berhasil memberi pengaruh pada penontonnya hingga mengubah perilaku mereka. Dengan demikian, beauty vlogger saat ini berperan sebagai penggerak terbesar bagi end user (konsumen) dalam hal pengambilan keputusan membeli produk, yaitu sebagai agen untuk meyakinkan end user bahwa produk yang mereka bicarakan tersebut layak beli (Febriana \& Yulianto, 2018; Lee \& Watkins, 2016; Verhellen, Dens \& Pelsmacker, 2013; Martawilaga \& Purwanegara, 2016; Erkan \& Evans, 2016; Rahmi, Sekarasih \& Sjabadhyni, 2016).

Karena itu, sebagai sarana promosi baru dalam industri bisnis media, vlogger tak bisa dilepaslan dari konsep influencer/prominent user/opinion leader yang pada saat ini berkembang pesat (Marwick \& Boyd, 2011; Palinoan, 2017). Sementara itu Rahmawan, Hafiar dan Narotama (2017) menemukan bahwa lewat kreativitas vlogger serta berbagai strategi presentasi diri, para vlogger berhasil menciptakan sebuah persona sehingga dapat disukai banyak orang, baik oleh subscribers (pelanggan) channel mereka maupun khalayak luas. Selain itu, berbekal popularitas yang dapat dilihat dari jumlah subscriber, traffic, jumlah respon (seperti like dan komentar yang tinggi), para vlogger kemudian dianggap memiliki pengaruh (influence) tinggi kepada khalayaknya.

Hal ini juga didukung oleh penelitian yang dilakukan oleh David, Sondakh dan Harilama (2017) yang menjelaskan mengenai hubungan searah antara konten vlog dan sikap mahasiswa Program Studi IImu Komunikasi FISIP Universitas Sam Ratulangi. Jika konten vlog sering ditonton maka akan terjadi pembentukan sikap pada mahasiswa. Selain itu, vlogger juga 
dinilai oleh para mahasiswa sebagai sosok yang dapat dipercaya mengenai hal-hal yang dibicarakannya baik sekedar pendapat ataupun ulasan mengenai sebuah produk. Vlogger juga ahli dalam membuat video yang menarik dan bagus dalam mengedit hasil video sehingga dapat dinikmati oleh penonton.

Para penonton video yang dibuat beauty vlogger pun demikian. Semakin sering seseorang menonton video tentang kecantikan seperti makeup dan skin care maka akan terjadi pembentukan sikap dalam memilih produk makeup dan penggunaan teknik-teknik makeup sesuai dengan video yang ditonton. Pembentukan sikap tersebut hingga memengaruhi keputusan seseorang dalam membeli produk. Jadi, beauty vlogger adalah sosok yang dianggap andal, mumpuni dan dipercaya dalam dunia kecantikan, khususnya mengenai makeup. Apa pun pendapat atau ulasan yang diberikan beauty vlogger tentang sebuah produk akan mejadi bahan pertimbangan para penontonnya.

\section{KESIMPULAN}

Sebuah makna muncul dari hubungan khusus antara kata (sebagai simbol verbal) dan manusia. Makna tak melekat pada kata-kata, tapi kata-kata membangkitkan makna dari pikiran orang. Jadi, tak ada hubungan langsung antara suatu objek dan simbol yang digunakan untuk merepresentasikannya. Selain itu, makna tidak terletak pada kata-kata, melainkan pada manusia. Kita menggunakan kata-kata untuk mendekati makna yang ingin kita komunikasikan. Tetapi, kata-kata ini tidak secara sempurna dan lengkap dapat menggambarkan makna yang dimaksud. Demikian pula, makna yang didapat pendengar dari pesan-pesan yang kita sampaikan akan sangat berbeda dengan makna yang ingin kita komunikasikan. Dalam konteks ini, para pegiat profesi beauty vlogger memaknai profesi mereka menjadi tiga makna besar, yaitu sebagai upaya aktualisasi diri, sebagai mata pencaharian, dan sebagai panutan.

\section{REFERENSI}

Arnus, Sri Hadijah. (2016). "Self Disclosure di Media Sosial pada Mahasiswa IAIN Kendari (Suatu Kajian Psikologi Komunikasi Pada Pengguna Media Sosial)”. Al-Izzah, 11(2): 1-18. Ayudhya, Fentira. (2017). "Instagram dan Presentasi Diri Mahasiswa (Studi Korelasional

Penggunaan Instagram Terhadap Presentasi Diri Mahasiswa Fakultas IImu Sosial dan IImu Politik Departemen IImu Komunikasi Universitas Sumatera Utara)". Flow, 3(5): 1-10. Ayun, Primada Qurrota. (2015). "Fenomena Remaja Menggunakan Media Sosial dalam Membentuk Identitas". Channel (Jurnal Komunikasi), 3(2): 1-6. 
Bachdar, Saviq. (12 Juni 2017). Beauty Vlogger dan Pengaruhnya Bagi Brand Kosmetik. Diakses dari: http://marketeers.com/beauty-vlogger-dan-pengaruhnya-bagi-brand-kosmetik/

Bazarova, Natalya N. and Yoon Hyung Choi. (2014). "Self-Disclosure in Social Media: Extending the Functional Approach to Disclosure Motivations and Characteristics on Social Network Sites". Journal of Communication, 64(4): 635-657.

Dahlan, Deddy. (17 September 2015). Dari Mana Asal Duit Para Youtuber? Diakses dari: https://ekonomi.kompas.com/read/2015/09/17/060700726/ Dari.Mana.Asal.Duit.Para.Youtuber

David, Eribka Ruthellia, Mariam Sondakh dan Stefi Harilama. (2017). “Pengaruh Konten Vlog dalam Youtube terhadap Pembentukan Sikap Mahasiswa IImu Komunikasi Fakultas IImu Sosial dan Politik Universitas Sam Ratulangi". e-journal "Acta Diurna", 6(1): 1-18.

Erkan, Ismail and Chris Evans. (2016). "Social Media or Shopping Websites? The Influence of EWOM on Consumers' Online Purchase Intentions". Journal of Marketing Communications, 24(6): 617-632.

Febriana, Mitha dan Edy Yulianto. (2018). "Pengaruh Online Consumer Review oleh Beauty Vlogger terhadap Keputusan Pembelian (Survei pada Mahasiswi Fakultas Ilmu Administrasi Universitas Brawijaya Angkatan 2014/2015 dan 2015/2016 yang Membeli dan Menggunakan Purbasari Matte Lipstick)". Jurnal Administrasi Bisnis (JAB), 58(1): 1-9.

Ingin dapat uang dari YouTube? Ini sistem monetisasinya. (8 September2016). Diakses dari: https://www.antaranews.com/berita/583383/ingin-dapat-uang-dari-youtube-ini-sistemmonetisasinya

J. Moor, Peter, A. Heuvelman and R. Verleur. (2010). "Flaming on YouTube". Computers in Human Behavior, 6(26): 1536-1546.

Kuswarno, E. (2009). Fenomenologi: Konsepsi, Pedoman, dan Contoh Penelitian. Bandung: Widya Padjajaran.

Lee, Jung Eun dan Brandi Watkins. (2016). "Youtube Vloggers Influence on Consumer Luxury Brand Perceptions and Intentions". Journal of Business Research, 69(12): 5753-5760.

Mahameruaji, Jimi N. (2018). "Bisnis Vlogging dalam Industri Media Digital di Indonesia". Jurnal ILMU KOMUNIKASI, 15(1): 61-74.

Mahendra, Bimo. (2017). "Eksistensi Sosial Remaja dalam Instagram (Sebuah Perspektif Komunikasi)". Jurnal Visi Komunikasi, 16(1): 151-160.

Martawilaga, Ayu Indriani dan Mustika Sufiati Purwanegara. (2016). “Information Acceptance of Electronic Words of Mouth (EWOM) and Purchase Intention through Haul Videos Youtube". Journal of Business and Management, 5(5): 651-660. 
Marwick, Alice \& Danah Boyd. (2011). "To See and Be Seen: Celebrity Practice on Twitter". Convergence: The International Journal Research into New Media Technologies, 17(2): 139-158.

Masyarakat Sadar Bersolek, Industri Kosmetik Naik 20 Persen. (20 Maret 2018). Diakses dari: https://www.cnnindonesia.com/ekonomi/20180320094246-92-284360/masyarakatsadar-bersolek-industri-kosmetik-naik-20-persen

Murthy, D. (2012). "Towards a Sociological Understanding of Social Media: Theorizing Twitter". Sociology, 46(6): 1059-1073.

Oktaviani, Kiki. (12 Juni 2017). 10 Artis Indonesia Merilis Produk Kosmetik. Diakses dari: https://wolipop.detik.com/read/2017/06/12/154957/3528028/234/10-artis-indonesiamerilis-produk-kosmetik

Palinoan, Imanuella Yunike. (2017). “Dampak Tayangan Vlog di YouTube terhadap Gaya Hidup Hedonis Siswa SMA Kristen Sunodia”. eJournal IImu Komunikasi, 5(2): 215-225.

Prambudi, I. (2010). Perubahan Mata Pencaharian dan Nilai Sosial Budaya Masyarakat. Surakarta: Universitas Sebelas Maret.

Putri, Anisha Saktian. (27 Februari 2018). Industri Kosmetik di Indonesia Meningkat Hingga Rp 36 Triliun. Diakses dari: https://www.vemale.com/cantik/112126-industri-kosmetikdi-indonesia-meningkat-hingga-rp-36-triliun.html

Rahmawan, Detta, Hanny Hafiar dan Jimi Narotama M. (2017). “Peran Vlogger sebagai Online Inflluencer dalam Industri Media Digital di Indonesia". PROMEDIA, 3(2): 183-206.

Rahmi, Yaumul, Laras Sekarasih dan Bertina Sjabadhyni. (2016). "The Influence of Beauty Vlog on Perceived Source Credibility and Purchase Intention". Makara Hubs-Asia, 20(2): 13-23.

Rismawaty. (2008). Kepribadian dan Etika Profesi. Yogyakarta: Graha IImu.

Sagiyanto, Asriyani dan Nina Ardiyanti. (2018). "Self Disclosure melalui Media Sosial Instagram (Studi Kasus pada Anggota Galeri Quote)". Nyimak Journal of Communication, 2(1): 8194.

Satori, Djam'an. (2005). Profesi Keguruan. Jakarta: Universitas Terbuka.

Seehan, Alex. (12 Januari 2016). 3 Reasons Why Vloggers have Power in PR. Diakses dari: https://mediahq.com/blog/2016/01/12/3-reasons-why-vloggers-have-power-in-pr/

Soetanto, C. (2016). Aktualisasi Diri pada Wanita Karir yang Mengurus Rumah Tangga. Yogyakarta: Universitas Sanata Dharma.

Subi, Akto. (13 April 2018). Rachel Goddard, Beauty Vlogger Kocak Dengan Gaya Kece \& Make-up Flawless! Diakses dari: https://www.kapanlagi.com/showbiz/selebriti/nomineerachel-goddard-beauty-vlogger-kocak-dengan-gaya-kece-38-make-up-flawless71968a.html 
Suwinardi. (2017). "Profesionalisme dalam Bekerja". ORBITH, 13(2): 81-85.

Tolson, A. (2010). "A New Authenticity? Communicative Practices on Youtube". Critical Discourse Studies, 7(4): 277-289.

Verhellen, Yann, Nathalie Dens and Patrick De Pelsmacker. (2013). "Consumer Responses to Brands Palced in Youtube Movies: The Effect of Prominence and Endorser Expertise". Journal of Electronic Commerce Research, 14(4): 287-303.

West, R., \& Turner, L. H. (2007). Pengantar Teori Komunikasi: Analisis dan Aplikasi. Jakarta: Salemba Humanika.

YouTube: Annual Beauty Content Views 2009-2017. Diakses dari: https://www.statista.com/ statistics/294655/youtube-monthly-beauty-content-views/

\section{Wawancara}

Zuariah, Jihan Putri. (30 Januari 2018). Wawancara pribadi.

Saelynda, Alifa Ratu. (6 Januari 2018). Wawancara pribadi. 
